ROCZNIKI PEDAGOGICZNE

Tom 12(48), numer $4-2020$

DOI: https://doi.org/10.18290/rped20124-9

GRZEGORZ GODAWA

KATARZYNA KUTEK-SŁADEK

\title{
ZDALNE NAUCZANIE W SYTUACJI PANDEMII COVID-19 W OPINII RODZICÓW UCZNIÓW SZKÓŁ PODSTAWOWYCH
}

\section{WSTĘP}

Zdalne nauczanie, w różnym zakresie obecne w polskiej edukacji, w sytuacji pandemii COVID-19 niespodziewanie stało się codzienną praktyką wielu polskich rodzin uczestniczących $\mathrm{w}$ procesie edukacji dzieci. Nowe okoliczności są uzasadnieniem podjęcia badań empirycznych pokazujących uwarunkowania, przebieg i ewaluację edukacji. Niniejszy projekt wpisuje się w ten postulat poprzez badawczą eksplorację zadań rodziców współpracujących ze szkołą. Udzielenie głosu rodzicom na temat realizacji procesu zdalnego kształcenia jest włączeniem ich w proces optymalizacji edukacji, ponieważ ich opinie pokazują, w jakich obszarach zdalna edukacja funkcjonuje prawidłowo, a gdzie są widoczne jej braki (Mann, 2020). W tym celu zostanie przeprowadzona analiza ilości czasu poświęcanego przez rodziców na naukę z dzieckiem oraz ogólna i szczegółowa ocena zdalnej edukacji. Zostanie sprawdzona zależność między czasem przeznaczonym na edukację a jej oceną. Istotne będzie także zbadanie związku między ilością czasu przeznaczonego na edukację dziecka a realizacją codziennych funkcji rodziny.

Dr hab. Grzegorz Godawa - Katedra Pedagogiki Społecznej, Wydział Nauk Społecznych, Uniwersytet Papieski Jana Pawła II w Krakowie; adres do korespondencji: ul. Kanonicza 25, 31-002 Kraków; e-mail: grzegorz.godawa@upjp2.edu.pl; ORCID: https://orcid.org/0000-0002-2283-3965.

Dr Katarzyna KuteK-SŁadeK - Katedra Pedagogiki Społecznej, Wydział Nauk Społecznych, Uniwersytet Papieski Jana Pawła II w Krakowie; adres do korespondencji: ul. Kanonicza 25, 31-002 Kraków; e-mail: katarzyna.kutek_sladek@upjp2.edu.pl; ORCID: https://orcid.org/0000-0003-0374$813 \mathrm{X}$. 


\section{NAUCZANIE NA ODLEGŁOŚĆ}

Współczesne nauczanie na odległość można zdefiniować jako metodę prowadzenia procesu dydaktycznego w warunkach, gdy uczniowie lub studenci oraz nauczyciele są fizycznie oddaleni od siebie. Uczenie i zdobywanie wiedzy na odległość polega więc w dużym stopniu na jej samodzielnym opanowaniu (Juszczyk, 2003, s. 872). Dokonuje się ono przy użyciu różnych mediów, które umożliwiają nawiązanie interakcji między nauczycielem i uczniami. Dzięki niej możliwy jest przekaz treści kształcenia. W tym znaczeniu Holmberg (2008, s. 9) określa je jako nauczanie zapośredniczone. Inicjatorem i prowadzącym proces nauczania jest nauczyciel, ale rzeczywistą kontrolę nad przebiegiem i efektami procesu kształcenia sprawuje uczeń (Kiryakova, 2009, s. 30). Nauczanie na odległość może mieć charakter synchroniczny (online), gdy jest prowadzone w czasie rzeczywistym, lub asynchroniczny, gdy materiały są udostępnione uczniom niezależnie od czasu (Heba, 2009, s. 147-148). Kształcenie zdalne, kształcenie na odległość, e-edukacja czy e-learning to pojęcia opisujące różne aspekty tego samego procesu. Może on być realizowany w całości na odległość bądź w formie komplementarnej, stosującej łącznie tradycyjne i wirtualne metody nauczania (Michałowski, Myka, 2014, s. 7).

Należy zaznaczyć, iż nauczanie na odległość jest odpowiedzią nie tylko na trudności związane z fizycznym dostępem uczniów do kształcenia tradycyjnego. Posiada ono także inne walory, np. możliwość uczenia się w dowolnym czasie i miejscu, niższe koszty uczenia się, brak konieczności dojeżdżania na zajęcia, elastyczność w planowaniu zajęć. Nie brak też mankamentów tej formy kształcenia, wśród których można wymienić trudności w skupieniu się, konieczność posługiwania się skomplikowanymi technologiami informatycznymi, osłabienie interakcji społecznych czy relatywnie słaby kontakt uczniów z nauczycielem (Sadeghi, 2019, s. 83-84).

W Polsce kształcenie na odległość najszerzej rozwinęło się na poziomie szkolnictwa wyższego, do czego przyczyniły się korzystne regulacje prawne (Dz.U. 2018, poz. 1861). Zdecydowanie mniejsze możliwości rozwoju tej formy nauczania i uczenia się były dostępne na niższych szczeblach edukacji (Dz.U. 2012, poz. 186 oraz Dz.U. 2012, poz. 1152 z późn. zm.), co znacznie utrudniało wdrażanie e-learningu w szkołach podstawowych, gimnazjach i szkołach ponadgimnazjalnych. Ta forma nauczania realizowana była w niektórych szkołach, zwłaszcza prywatnych, jako atrakcyjne uzupełnienie tradycyjnego kształcenia (Szkoły z e-learningiem w Polsce, 2020). Kształcenie na odległość zyskało nową formułę i nowe znaczenie w sytuacji pandemii COVID-19. 


\section{ZDALNE NAUCZANIE W SYTUACJI PANDEMII}

Wystąpienie koronawirusa i związanej z nim sytuacji zagrożenia COVID-19 spowodowało duże zmiany zarówno w przepisach prawnych, jak i w praktycznej realizacji nauczania na odległość. W Polsce zasadnicze zmiany dokonywały się równolegle do rozwoju pandemii, a ich wyznacznikami była specustawa oraz rozporządzenia Ministra Edukacji Narodowej (Dz.U. 2020, poz. 374 z późn. zm., Dz.U. 2020, poz. 410 z późn. zm., Dz.U. 2020, poz. 493 z późn. zm.).

Zaistniałe zmiany $\mathrm{w}$ przepisach prawnych umożliwiły prowadzenie kształcenia na odległość w okresie czasowego ograniczenia funkcjonowania szkół i placówek oświatowych, które obowiązywały najpierw od 12 marca do 10 kwietnia 2020 r., następnie do 24 kwietnia 2020 r. i 24 maja 2020 (stan na dzień 9 maja 2020). Rozporządzenia określiły również zasady prowadzenia nauczania na odległość, a także oceniania i klasyfikowania uczniów. Należy podkreślić, że nowe przepisy nie tylko otworzyły drogę do realizacji zdalnego nauczania, ale także zobowiązały dyrektorów szkół do zorganizowania tego nauczania w prowadzonych przez nich placówkach. W telewizji publicznej oraz $\mathrm{w}$ serwisie internetowym polskiego rządu udostępniono informacje i materiały dydaktyczne służące usprawnieniu zdalnych lekcji oraz wskazano sposoby zabezpieczenia dzieci przed nadużyciami zawiązanymi z długim korzystaniem z sieci (Poradnik dla rodziców, 2020).

Przepisy określające, w jaki sposób ma się odbywać nauczanie na odległość, odnoszą się do działań dyrekcji, nauczycieli, uczniów oraz rodziców. Zwrócenie uwagi na rolę rodziców w zdalnym nauczaniu dzieci wydaje się szczególnie istotne, gdyż to na ich barkach spoczęło zadanie współpracy $\mathrm{z}$ dzieckiem oraz szkołą w zakresie realizacji podstawy programowej.

\section{METODOLOGIA BADAŃ WŁASNYCH}

Przedstawione wyniki są częścią projektu badawczego „Zdalne nauczanie uczniów szkół podstawowych w sytuacji pandemii COVID-19". Badania przeprowadzono w grupie 358 rodziców, których przynajmniej jedno dziecko kształci się w klasach 1-6 szkoły podstawowej. W badaniach uczestniczyło 337 kobiet i 21 mężczyzn. Średni wiek badanych wynosił 37.91 lat $(S D=5,37)$. Badania przeprowadzono w kwietniu 2020 r. techniką sondażu, z zastosowaniem ankiety skierowanej drogą elektroniczną do rodziców, przy zachowaniu pełnej anonimowości respondentów. W badaniach wykorzystano 
autorski kwestionariusz, który zawierał 43 pytania skoncentrowane na problematyce zdalnego nauczania. Zbadano następujące problemy: zaangażowanie rodziców w zdalną edukację dziecka w wymiarze czasowym, ocenę zdalnego nauczania dzieci w sytuacji pandemii koronawirusa, związek między czasem spędzanym przez rodziców na pomaganiu dziecku $\mathrm{w}$ nauce a oceną tej formy edukacji, związek między czasem przeznaczanym na edukację dziecka a realizacją codziennych zadań rodzicielskich.

\section{WYNIKI}

Analiza uzyskanego materiału badawczego pozwoliła na opisanie i wyjaśnienie zamierzonych obszarów badawczych.

\section{Czas poświęcony na naukę z dzieckiem}

Aby odpowiedzieć na pytanie zawarte w pierwszym problemie badawczym, dokonano analizy częstości wypowiedzi rodziców.

Wykres 1. Ilość czasu poświęcanego dziennie na pomoc dziecku (dzieciom) w nauce

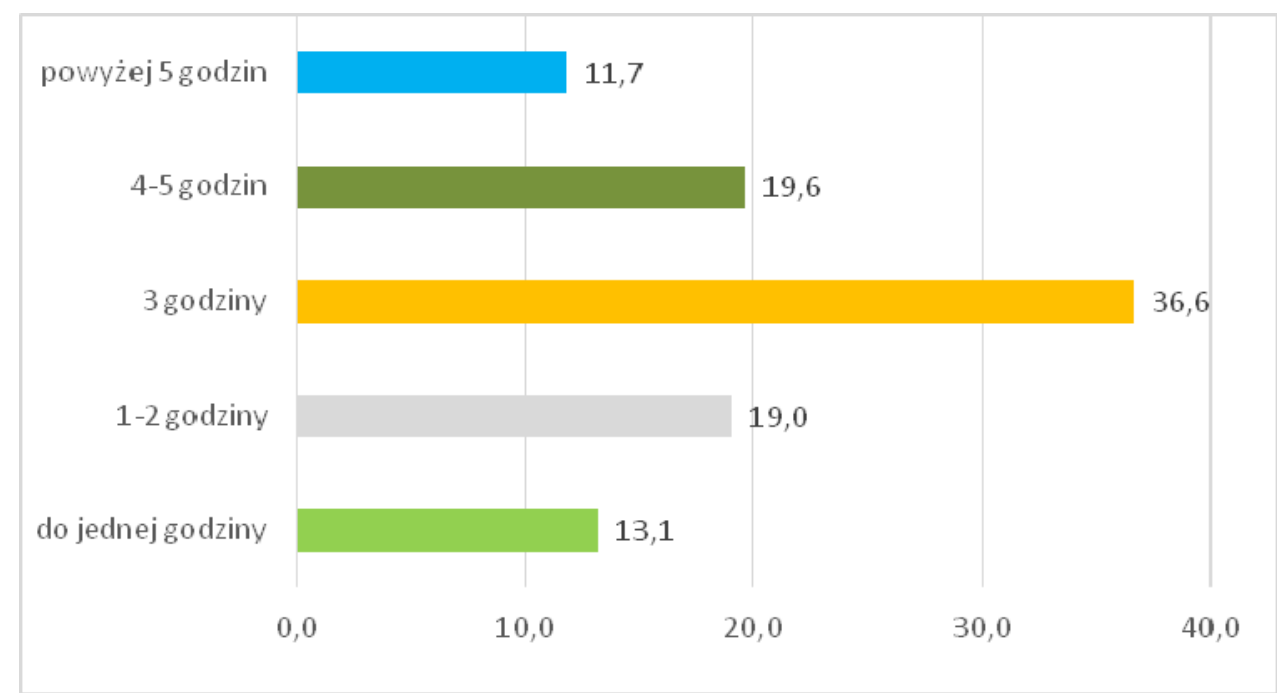

Warto zaznaczyć, że 76\% badanych jest rodzicem dwojga lub trojga dzieci, a 26,2\% rodziców posiada dwoje lub troje dzieci kształcących się w klasach 1-6. To oznacza, że dla stosunkowo dużej grupy badanych codzienne 
funkcjonowanie wiąże się z koniecznością poświęcenia uwagi i czasu więcej niż jednemu dziecku. Graficzny rozkład głosów rodziców poświęcających swój czas na pomaganie dziecku w nauce jest symetryczny. Oś symetrii stanowi przedział „3 godziny dziennie”, wokół którego rozkładają się pozostałe wybory. Jest to przedział, który zdobył największą liczbę głosów $(36,6 \%)$.

W badanej grupie można również zauważyć dość równomierny rozkład procentowy głosów, co pozwala na wyodrębnienie trzech podgrup badanych. Prawie jedna trzecia badanych poświęca dziennie do dwóch godzin na pomoc dziecku w nauce. Podobny procent rodziców przeznacza dziennie 3 godziny, a 31,3\% pracuje z dziećmi więcej niż 3 godziny.

\section{Ocena zdalnego nauczania}

Badani respondenci oceniali zdalne nauczanie za pomocą zaproponowanej skali ocen: niedostatecznie, dostatecznie, dobrze, bardzo dobrze. Pierwsze z pytań w tym obszarze dotyczyło ogólnej oceny nauczania dzieci na odległość. Odpowiedzi rodziców na to pytanie zawarto na wykresie 2.

Wykres 2. Ogólna ocena zdalnego nauczania

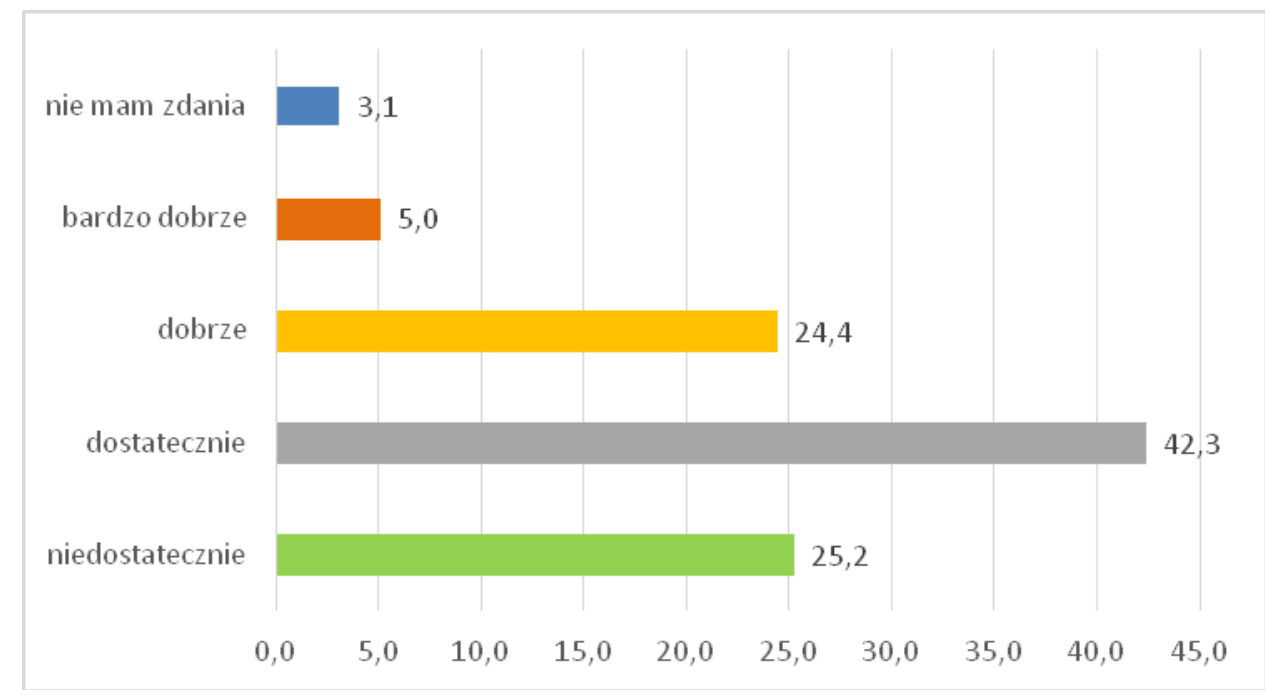

$\mathrm{Z}$ analizy wykresu 2 wynika, że 67,5\% głosów respondentów koncentrowało się wokół niskiej oceny jakości tej edukacji. Zaledwie w 5\% wypowiedzi edukacja ta jest oceniana bardzo dobrze, co nie równoważy jednej czwartej głosów oddanych na kategorię „niedostatecznie”. Znikomy $(3,1 \%)$ procent badanych, którzy nie posiadają własnej opinii na ten temat, pokazuje, że 
sytuacja zagrożenia sprzyja precyzowaniu poglądów. Dla pełniejszego ujęcia oceny zdalnej edukacji przeanalizowano jej wybrane składniki.

Wykres 3. Ocena wybranych składników kształcenia

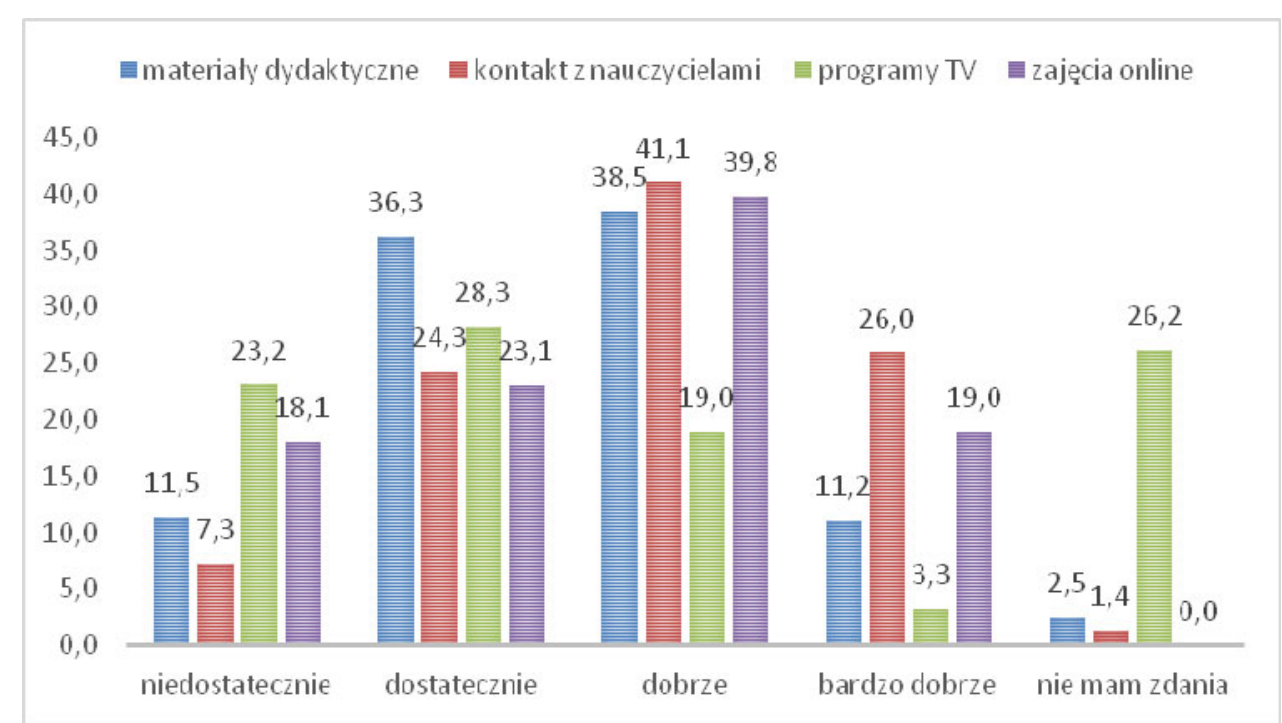

Spośród wymienionych składników zdalnej edukacji najwięcej wysokich ocen respondenci przyznali kontaktowi z nauczycielami $(67,1 \%)$. To oznacza, że w opinii badanych rodziców dostępność nauczycieli i ich gotowość do kontaktu jest duża. Stanowi to ważny czynnik kształtujący jakość zdalnego nauczania, gdyż jego powodzenie jest uwarunkowane współpracą podmiotów wychowania. Stosunkowo dużo głosów dowartościowało zdalne zajęcia prowadzone $\mathrm{w}$ rzeczywistym czasie, których realizację wykazała prawie połowa respondentów.

Alternatywą bądź uzupełnieniem zajęć online jest przesyłanie przez nauczycieli uczniom materiałów, które należy zrealizować. Biorąc pod uwagę wskazania respondentów dotyczące ich jakości, można przyjąć, że w umiarkowanym stopniu spełniają one swoją rolę. Znacznie gorzej są oceniane materiały edukacyjne dostępne w telewizji. Oddano aż 23,2\% głosów w kategorii najniższej oceny, co w połączeniu z głosami oceniającymi je na poziomie dostatecznym $(28,3 \%)$ wskazuje, że dla nieco ponad połowy rodziców deklarujących znajomość tych programów są one niskiej jakości. Co ciekawe, aż $26,1 \%$ spośród rodziców deklarujących znajomość tych programów nie ma na ich temat zdania. Być może dlatego, że programy telewizyjne służące zdalnemu nauczaniu zostały uruchomione nieco później niż samo nauczanie. 


\section{Zależność między czasem spędzanym na pomaganiu dziecku w nauce a oceną zdalnej edukacji}

W celu udzielenia odpowiedzi na trzecie pytanie badawcze i przetestowania postawionych hipotez przeprowadzono analizy statystyczne przy użyciu pakietu IBM SPSS Statistics w wersji 26. Za jego pomocą wykonano analizę podstawowych statystyk opisowych. Postanowiono przetestować związek między czasem spędzanym na pomaganiu dziecku w nauce a oceną zdalnej edukacji. W tym celu przeprowadzono analizy korelacji ze współczynnikiem rho Spearmana. Za poziom istotności statystycznej przyjęto klasyczny próg $\alpha=0,05$.

Wyniki tych analiz wskazują na istotny statystycznie, ujemny związek między czasem spędzanym na pomaganiu dziecku w nauce a oceną procesu nauczania dzieci na odległość (związek słaby: $r_{s}=-0,16 ; \mathrm{p}=0,002$ ). Oznacza to, że im więcej czasu badani poświęcają dzieciom, aby pomóc im w nauce, tym gorzej oceniają oni proces nauczania dzieci na odległość.

\section{Zależność czasu spędzanego na pomaganiu dziecku z realizacją co- dziennych zadań rodziny}

Dokonano również analizy korelacji między czasem spędzanym na pomaganiu dziecku w nauce a wyzwaniami codziennego funkcjonowania rodziny. Wyniki analizy wskazują na istotny statystycznie, dodatni związek o umiarkowanej sile $\left(r_{s}=0,32 ; p<0,001\right)$. To oznacza, że występuje umiarkowane powiązanie czasu spędzanego na pomaganiu dziecku w nauce z wyzwaniami codziennego życia rodziny. Wynika $z$ tego, że im więcej badani poświęcają dziecku czasu na pomoc w nauce, tym większym wyzwaniem jest dla nich realizacja codziennych zadań rodziny.

\section{WNIOSKI}

Komentując pierwszy problem badawczy, uzyskane wyniki można odnieść do rezultatów badań przeprowadzonych przez portal edukacyjny LIBRUS (Nauczanie zdalne, 2020). Zaprezentowane wyniki nie są w pełni porównywalne, można jednak zauważyć podobne tendencje: liczba trzech godzin poświęcanych na edukację $\mathrm{w}$ domu w obu badaniach jest stosunkowo najczęściej wybierana, a procent rodziców spędzających 1-2 godziny jest bardzo zbliżony. O ile w badaniach ilości czasu spędzanego na odrabianiu 
z dzieckiem lekcji przed pandemią COVID-19 55\% rodziców pomagało swemu dziecku codziennie lub kilka razy w tygodniu (Ile czasu rodzice poświęcaja swoim dzieciom?, 2014), o tyle podczas pandemii ta powinność zabiera znacznie więcej czasu i dotyczy większej liczby rodziców.

Drugi i trzeci problem badawczy dotyczył oceny zdalnej edukacji dzieci. Ogólna ocena tego procesu jest niska lub bardzo niska dla 67,5\% oddanych głosów. Prawie 30\% wyborów wskazało na jej pozytywny lub bardzo pozytywny obraz. Otrzymane wyniki pokazują nieco mniej optymistyczny obraz tego procesu niż rezultaty badań przeprowadzonych przez portal Wirtualna Polska. Badania pokazały, że zdecydowani krytycy oraz sprzyjający tej ocenie stanowili $44 \%$ badanych, a rodzice oceniający ją pozytywnie stanowili $42 \%$ badanej populacji (Smykla, 2020).

Ocena wybranych składowych edukacji pozwala dostrzec stosunkowo wysoką ocenę kontaktu z nauczycielami $(67,1 \%)$ oraz zajęć online $(58,8 \%)$. Odpowiada to potrzebom dzieci, które zgłaszają rodzice - za kontaktem z nauczycielami tęskni $54 \%$ dzieci (w: Nauczanie zdalne, 2020). Zajęcia online, choć są prowadzone w niespełna połowie placówek $(46,8 \% \mathrm{w}$ badaniach własnych, $46 \% \mathrm{w}$ badaniach LIBRUS), mają istotne znaczenie edukacyjne i cieszą się dobrą opinią. Są formą kontaktu z nauczycielem, uatrakcyjniają proces kształcenia i odciążają rodziców.

Ostatnim problemem badawczym był związek między czasem spędzanym przez rodziców na pomaganiu dziecku w nauce a oceną tej formy edukacji. Wyniki wskazują na istotny statystycznie, ujemny związek między tymi zmiennymi. Z niego wynika, że rodzice oceniający proces zdalnej edukacji odkrywają jego mankamenty na miarę swego zaangażowania czasowego w pomaganie dziecku. Są to więc oceny oparte na osobistym doświadczeniu, a nie tylko na obiegowych przekonaniach czy poglądach. Zastanawia brak istotnego statystycznie związku między poświęcanym czasem a oceną poszczególnych składowych nauczania. Zależności tej należy szukać w innych związkach, co otwiera kolejne perspektywy badawcze. Autorskie badania pokazały również ostatnią zależność, z której wynika, że dla rodziców, z których $67 \%$ pracuje zawodowo, pomaganie dziecku w nauce jest dużym wyzwaniem. Nie oznacza to, że rodzice nie dostrzegają pozytywnych stron takiej formy edukacji. W wielu przypadkach są po prostu przeciążeni obowiązkami, a to świadczy o tym, że traktują swoje zadania odpowiedzialnie.

Analiza wyników badań inspiruje do podejmowania działań. Winny one zmierzać przynajmniej w dwóch kierunkach: ku podniesieniu jakości realizacji procesu kształcenia ze strony szkoły i wzmocnieniu rodziców w realizacji 
ich zadań. Warto zauważyć, że oba te kierunki się wzajemnie dopełniają wysoka jakość nauczania odciąża rodziców, gdyż zmniejsza ilość czasu niezbędnego do odrobienia zadań. $Z$ kolei wsparci rodzice przyczyniają się do osiągania lepszych efektów nauczania swoich dzieci.

\section{BIBLIOGRAFIA}

HeBA, A. (2009). Nauczanie na odległość - wczoraj i dziś. Nauczyciel i Szkoła, 3-4(44-45), 145-152.

Holmberg, B. (2008). The Evolution, Principles and Practices of Distance Education. Oldenburg: Bibliotheks- und Informationssystem der Univ.

Ile czasu rodzice poświęcaja swoim dzieciom?, http://www.tnsglobal.pl/archiwumraportow/files/2014 /07/K.047_Ile-czasu-rodzice-poswiecaja-swoim-dzieciom_O05a-14.pdf (dostęp: 1.05.2014).

JuszczyK, S. (2003). Kształcenie na odległość (online). W: T. PILch (red.), Encyklopedia Pedagogiczna XXI wieku, t. 2 (s. 872-878), Warszawa: Wydawnictwo Akademickie „Żak”.

Kiryakova, G. (2009). Review of Distance Education. Trakia Journal of Sciences, 7(3), 29-34.

Mann, M. (2020). Coronavirus (COVID-19) Guidance for Schools, https://www.nais.org/articles /pages/additional-covid-19-guidance-for-schools/ (dostęp: 1.05.2020).

MichaŁowski, R., MYKA, W. (2014). Jak wdrażać ksztatcenie na odlegtość w ksztatceniu ustawicznym $w$ formach pozaszkolnych krok po kroku. Warszawa: KOWEZIU.

Nauczanie zdalne. Jak wyglada w naszych domach. Raport z badania ankietowego, https://portal. librus.pl/rodzina/artykuly/nauczanie-zdalne-jak-wyglada-w-naszych-domach-pobierz-raport (dostęp: 1.05.2020).

Poradnik dla rodziców, https://www.gov.pl/web/zdalnelekcje/poradnik-dlarodzicow (dostęp: 21.04.2020).

Rozporządzenie MNiSW z dnia 27 września 2018 r. w sprawie studiów, par. 12-13 (Dz.U. 2018, poz. 1861).

Rozporządzenie MEN z dnia 11 stycznia 2012 r. w sprawie kształcenia ustawicznego w formach pozaszkolnych, par 20, ust. 5 (Dz.U. 2012, poz. 186 oraz Dz.U. 2012, poz. 1152 z późn. zm.),

Rozporządzenie MEN z dnia 11 marca 2020 r. w sprawie czasowego ograniczenia funkcjonowania jednostek systemu oświaty w związku z zapobieganiem, przeciwdziałaniem i zwalczaniem COVID-19 (Dz.U. 2020, poz. 410, z późn. zm.).

Rozporządzenie MEN z dnia 20 marca 2020 r. w sprawie szczególnych rozwiązań w okresie czasowego ograniczenia funkcjonowania jednostek systemu oświaty w związku z zapobieganiem, przeciwdziałaniem i zwalczaniem COVID-19 (Dz.U. 2020, poz. 493, z późn. zm).

SADEGHI, M. (2019). A Shift from Classroom to Distance Learning: Advantages and Limitations. International Journal of Research in English Education, 4(1), s. 80-88.

Szkoły z e-learningiem $w$ Polsce. Nauczanie na odległość w polskich szkołach, https://www.our kids.net/pl/szkoly-e-learning.php\#maincontent (dostęp: 30.04.2020).

SMYKLA, D. Rodzice o edukacji zdalnej. Sa zgodni, https://www.o2.pl/artykul/rodzice-o-edukacji -zdalnej-sa-zgodni-badanie-6497666398705281a (dostęp: 1.05.2020).

Ustawa z dnia 2 marca 2020 r. o szczególnych rozwiązaniach związanych z zapobieganiem, przeciwdziałaniem i zwalczaniem COVID-19, innych chorób zakaźnych oraz wywołanych nimi sytuacji kryzysowych (Dz.U. 2020, poz. 374). 


\title{
ZDALNE NAUCZANIE W SYTUACJI PANDEMII COVID-19 W OPINII RODZICÓW UCZNIÓW SZKÓŁ PODSTAWOWYCH
}

\begin{abstract}
STRESZCZENIE
Zdalne nauczanie w sytuacji pandemii COVID-19 niespodziewanie stało się codzienną praktyką wielu polskich rodzin uczestniczących w procesie edukacji dzieci. Nowe okoliczności są uzasadnieniem podjęcia badań empirycznych pokazujących uwarunkowania, przebieg i ewaluację edukacji. Celem niniejszego artykułu jest zaprezentowanie opinii rodziców dzieci klas 1-6 szkoły podstawowej na temat realizacji procesu zdalnego kształcenia. Aby ukazać zalety i mankamenty zdalnej edukacji przeprowadzono analizę ilości czasu poświęcanego przez rodziców na naukę z dzieckiem oraz ogólną i szczegółową ocenę tego procesu. Analiza wyników badań pokazała, jak nauczanie zdalne wygląda w rzeczywistości i które obszary wymagają dalszej pracy.
\end{abstract}

Słowa kluczowe: zdalne nauczanie; pandemia COVID-19; edukacja; rodzice.

\section{DISTANCE TEACHING IN THE SITUATION OF THE COVID-19 PANDEMIC IN THE OPINION OF PARENTS OF PRIMARY SCHOOL STUDENTS}

\section{SUMMARY}

Distance teaching, present in various scopes in Polish education, during the COVID-19 pandemic it unexpectedly became a daily practice of many Polish families participating in the process of educating children. The new circumstances constitute a justification of undertaking empirical research showing the conditions, course, and evaluation of education. The purpose of this article is to present the opinions of parents' of primary school children in grades 1-6 concerning the implementation of the distance education process. In order to present the advantages and disadvantages of remote education, an analysis was carried out concerning the amount of time devoted by parents to learn with the child, as well as a general and detailed assessment of this process. The analysis of test results showed what e-learning looks like in reality and which areas require further work.

Keywords: distance teaching; COVID-19 pandemic; education; parents. 